\section{Prostrate Growth Habit Enhances Fresh-market Tomato Fruit Yield and Quality}

Richard H. Ozminkowski, Jr. ', Randolph G. Gardner², Warren R. Henderson $^{2}$, and Robert H. Moll ${ }^{3}$

Department of Horticultural Science, Box 7609, North Carolina State University, Raleigh, NC 276957609

Additional index words. Lycopersicon esculentum, plant habit, ground culture, fruit defects

Abstract. Two inbred lines of fresh-market tomato (Lycopersicon esculentum Mill.), NC 20G-1 and NC 53G-1, both exhibiting prostrate growth habit (PGH), were crossed with the upright growth habit cultivar Piedmont and advanced to the $F_{2}$ generation. Plants of each $F_{2}$ population were grown without plant support on black plastic and subjectively rated in field plots for PGH. Extreme upright and prostrate plants were chosen from each $F_{2}$ population for harvest. Mean comparisons between plants of extreme upright and prostrate habit showed increased total and marketable yields from plants with a prostrate habit. Decay and groundscarring of fruit were less in prostrate than in normally upright plants; the percentage of misshapen fruit was similar in both. The PGH character may be useful in increasing total and marketable yield of groundculture tomatoes.

In ground culture, tomato plants are susceptible to lodging from wind and rain. Lodging reduces fruit yield and quality (Adelana, 1980). Common measures used to overcome this problem are staking and trellising, both being costly in materials, labor, and time (Adelana, 1976). In studies involving the effects of staking and pruning on yield of tomato, Jensen (1957) and Mangal et al. (1981) reported higher marketable and total yields, respectively, when plants were staked and pruned, rather than left lying on the ground. In contrast, Voinea and Bunescu (1957) reported lower total yields in staked and pruned plants. Adelana (1980) concluded there was a low correlation between lodging and total yield. However, lodging of unstaked plants does cause significant reductions in fruit quality (Adelana, 1976, 1980; Jensen, 1957). Alternative methods of improving yield and quality without mechanical support may increase profitability of freshmarket tomato production.

Several breeding lines with prostrate growth habit (PGH) have been developed in the North Carolina fresh-market tomato breeding program. PGH plants exhibit wide lateral branch

Received for publication 7 Aug. 1989. Paper no. 12272 of the Journal Series of the North Carolina Agricultural Research Service, Raleigh, NC 27695. This paper is a portion of the senior author's MS thesis. We acknowledge the technical assistance of Tom Eaker and Rebecca Wells. The cost of publishing this paper was defrayed in part by the payment of page charges. Under postal regulations, this paper therefore must be hereby marked advertisement solely to indicate this fact.

'Former Graduate Research Assistant. Present address: Dept. of Horticulture, The Ohio State Univ., 2001 Fyffe Ct., Columbus, OH 43210.

${ }^{2}$ Associate Professor.

${ }^{3}$ Professor of Genetics. angles (Ozminkowski et al., 1990) that result in plants with an open, spreading habit not prone to lodging, as is common with the upright habit. The objective of this study was to determine the effects of PGH on tomatofruit yield and quality.

Determinate inbred tomato lines NC 20G1 and NC 53G-1 served as sources of prostrate growth habit. NC 20G-1 is early in maturity, whereas NC 53G-1 is late in maturity with larger plants than 20G-1. Both lines were crossed in the greenhouse with the determinate, upright growth habit 'Piedmont' as the male parent, and then advanced to the $F_{2}$ generation. $\mathrm{F}_{2}$ populations were used to reduce genotype effects, since isogenic populations were not available.

Plants were started in a greenhouse and

Table 1. Yield attributes of first, second, and total harvests in two field-grown $F_{2}$ tomato populations of plants selected for extreme expression of upright or prostrate growth habit.

\begin{tabular}{|c|c|c|c|c|c|c|}
\hline \multirow{2}{*}{$\begin{array}{l}\text { Attribute and } \\
\text { growth habit }\end{array}$} & \multicolumn{3}{|c|}{ Harvests, 20G F } & \multicolumn{3}{|c|}{ Harvests, $53 \mathrm{G} \mathrm{F}_{2}$} \\
\hline & First & Second & Total & First & Second & Total \\
\hline \multicolumn{7}{|c|}{ Yield (kg/plant) } \\
\hline Upright & $1.4^{* *}$ & $5.8^{\mathrm{NS}}$ & $7.3^{*}$ & $1.7^{*}$ & $5.3^{* *}$ & $7.0^{* * *}$ \\
\hline Prostrate & 1.9 & 6.6 & 8.4 & 2.1 & 7.8 & 9.9 \\
\hline \multicolumn{7}{|c|}{$\begin{array}{l}\text { Marketable (kg/ } \\
\text { plant) }\end{array}$} \\
\hline Upright & $0.9^{* * *}$ & $3.8^{*}$ & $4.7^{* *}$ & $0.8^{* *}$ & $3.3^{* * *}$ & $4.0^{* * *}$ \\
\hline Prostrate & 1.5 & 4.8 & 6.3 & 1.5 & 4.9 & 6.5 \\
\hline \multicolumn{7}{|c|}{ Marketable (\%) } \\
\hline Upright & $62.5^{*}$ & $66.5^{*}$ & $65.2^{* *}$ & $43.5^{* * *}$ & $61.7^{\mathrm{NS}}$ & $57.7^{* *}$ \\
\hline Prostrate & 78.7 & 73.5 & 74.4 & 74.0 & 65.0 & 66.2 \\
\hline \multicolumn{7}{|l|}{ Decayed (\%) } \\
\hline Upright & $11.5^{\mathrm{NS}}$ & $6.8^{\mathrm{NS}}$ & $7.7^{\mathrm{Ns}}$ & $33.9^{* * *}$ & $15.0^{\mathrm{NS}}$ & $19.2^{* * *}$ \\
\hline Prostrate & 6.5 & 5.5 & 5.8 & 7.6 & 9.3 & 9.5 \\
\hline \multicolumn{7}{|c|}{ Groundscarred (\%) } \\
\hline Upright & $7.6^{*}$ & $11.4^{*}$ & $10.8^{* *}$ & $5.2^{\mathrm{NS}}$ & $7.5^{\mathrm{NS}}$ & $7.1^{\mathrm{NS}}$ \\
\hline Prostrate & 1.4 & 5.0 & 4.2 & 6.3 & 9.7 & 9.6 \\
\hline \multicolumn{7}{|l|}{ Misshapen (\%) } \\
\hline Upright & $23.3^{\mathrm{NS}}$ & $0.2^{\mathrm{NS}}$ & $5.2^{\mathrm{NS}}$ & $10.7^{\mathrm{NS}}$ & $0.0^{\mathrm{NS}}$ & $3.1^{\mathrm{NS}}$ \\
\hline Prostrate & 13.3 & 0.7 & 3.6 & 5.1 & 0.0 & 1.5 \\
\hline
\end{tabular}
decayed tissue was not necessarily present. transplanted into the field in Fletcher, N.C., on black plastic mulch as described by $\mathrm{Oz}-$ minkowski et al. (1990). Each $\mathrm{F}_{2}$ population (20G and 53G) contained 240 plants. The plants were not pruned. Plants of each $\mathrm{F}_{2}$ population were subjectively rated for plant growth habit 9 weeks after transplanting to the field. The rating scale was based on whole numbers from 1 through 5 , with $1=$ plants with the extreme upright habit and $5=$ those with extreme prostrate growth habit (Ozminkowski, 1988).

The first of two harvests was on 13 Aug. 1987, 9 weeks after transplanting. Fruit were harvested from 17 upright (rated 1) and 19 prostrate (rated 5) plants in the 20G $\mathrm{F}_{2}$ population and 19 upright and 14 prostrate plants in the $53 \mathrm{G} \mathrm{F}_{2}$ population. All fruit were removed from the first and second fruit clusters (inflorescences) at the first harvest. The second harvest was 6 days later with all fruit $>3.5 \mathrm{~cm}$ in diameter harvested. Total harvest values were computed as sums of both harvests.

Fruit from each plant were weighed and categorized as marketable, groundscarred, decayed, and/or misshapen. Marketable fruit were those of US \#1 or US \#2 grade (U.S. Dept. Agriculture, 1976). Fruit having blemishes without skin breakage were considered groundscarred. For decay, the blemishes penetrated the skin of the fruit but Only fruit having indentations caused by wedging between branches of the plant were classified as misshapen. A single fruit was placed into both the misshapen and groundscarred or decayed categories, as warranted. Differences between means of each yield attribute were tested using a two-tailed Student's $t$ analysis with unequal variances (Steele and Torrie, 1980).

Total yield of prostrate plants was greater than that of upright plants (Table 1). Prostrate plants also exhibited a higher marketable yield than did upright plants in each $\mathrm{F}_{2}$ population. The higher total and marketable 
yields of prostrate plants resulted in much higher marketable percentages for prostrate than upright plants. In the first and total harvests of the $53 \mathrm{G} \mathrm{F}_{2}$, unlike in the $20 \mathrm{G} \mathrm{F}_{2}$, there was a lower percentage of decayed fruit in prostrate than in upright plants. Only prostrate 20G $\mathrm{F}_{2}$ plants produced significantly fewer groundscarred fruit than did upright plants. The percentage of misshapen yield was similar for upright and prostrate plants.

Increased total yield in prostrate plants may be related to the PGH trait, although the possibility of favorable yield linkages was not tested. The open, spreading growth habit likely resulted in better exposure of foliage to light, possibly increasing photosynthesis per plant, and leading to greater fruit production.

The crown set (first harvest) of prostrate plants is well-supported above the ground, more so than later fruit sets (second harvest), and thus appeared to be less susceptible to decay or groundscarring. The lower percentage of decay for prostrate plants in the $53 \mathrm{G} \mathrm{F}_{2}$ but not in $20 \mathrm{G} \mathrm{F}_{2}$ may have been related to the larger plant habit of the former. The large, upright plant may have had a higher relative humidity within its canopy relative to the smaller plant. Surface blemishes on fruit within a larger plant may have led to decay, whereas those in a smaller, upright plant did not. In addition to greater marketable yield, plants exhibiting PGH were notably easier to harvest, although no quantitative data were obtained. Increased solar injury might be a potential problem in prostrate plants in some environments, but was not detected in our experiment.

\section{Literature Cited}

Adelana, B.O. 1976. The effects of staking on the growth and yield of tomato. E. Afr. Agr. For. J. 41:243-248.

Adelana, B.O. 1980. Relationship between lodging, morphological characters and yield of tomato cultivars, Scientia Hort. 13:143-148.

Jensen, J. 1957. Experiments on pruning and staking tomatoes in the field (in Danish). Tidsskr. Planteavl. 61:35-48. [Hort. Abstr. 27:2509: 1957.]

Mangal, J.L., A.S. Sidhu, and U.C. Pandey. 1981. Effect of staking and pruning on growth, earliness and yield of tomato varieties. Indian J. Agr. Res. 15(2):103-106.

Ozminkowski, R.H., Jr. 1988. The inheritance of prostrate growth habit in tomato and the effect of prostrate growth habit on fruit quality and yield of fresh market tomato. MS Thesis, North Carolina State Univ., Raleigh.

Ozminkowski, R.H., Jr., R.G. Gardner, R.H. Moll, and W.R. Henderson. 1990. Inheritance of prostrate growth habit in tomato. J. Amer. Soc. Hort. Sci. 115(4):674-677.

Steele, R.G.D. and J.H. Torrie. 1980. Principles and procedures-of statistics. 2nd ed. McGrawHill, New York.

U.S. Dept. of Agriculture. 1976. United States standards for grades of fresh tomatoes. 41 F.R. 11464.

Voinea, M. and D. Bunescu. 1957. The effect of pruning on the ripening and yield of tomatoes (in Romanian). Anal. Inst. Cercetari Agron. 24:369-377. [Hort. Abstr. 29:530; 1959.] 